\title{
COMMUNICATION
}

View Article Online

View Journal I View Issue

\section{Synthesis of substituted hydantoins in low melting mixtures $\dagger$}

Cite this: Chem. Commun., 2013 49, 5052

Received 17th February 2013, Accepted 17th April 2013

\author{
Sangram Gore, ${ }^{\text {ab }}$ Kiran Chinthapally, ${ }^{a}$ Sundarababu Baskaran*a and \\ Burkhard König*b
}

DOI: $10.1039 / \mathrm{c3cc4} 41254 \mathrm{~g}$

www.rsc.org/chemcomm

A novel domino synthesis of 1,3,5-trisubstituted hydantoin derivatives has been developed in low melting L-(+)-tartaric acid-DMU melt mixtures. The functionalized hydantoins are obtained in good yields from $\beta, \gamma$-unsaturated ketoacids and urea under environmentally benign and simple reaction conditions.

The hydantoin moiety is an important structural scaffold found in a number of biologically active compounds. ${ }^{1}$ Many hydantoin derivatives have been identified as anticonvulsant, antiulcer, antiarrhythmic, antimuscarinic, antiviral and antidiabetic agents. ${ }^{2-5}$ Moreover, hydantoin derivatives have also been used as antidepressants as well as platelet aggregation inhibitors. ${ }^{6}$ Aplysinopsin 1, isolated from the sponge

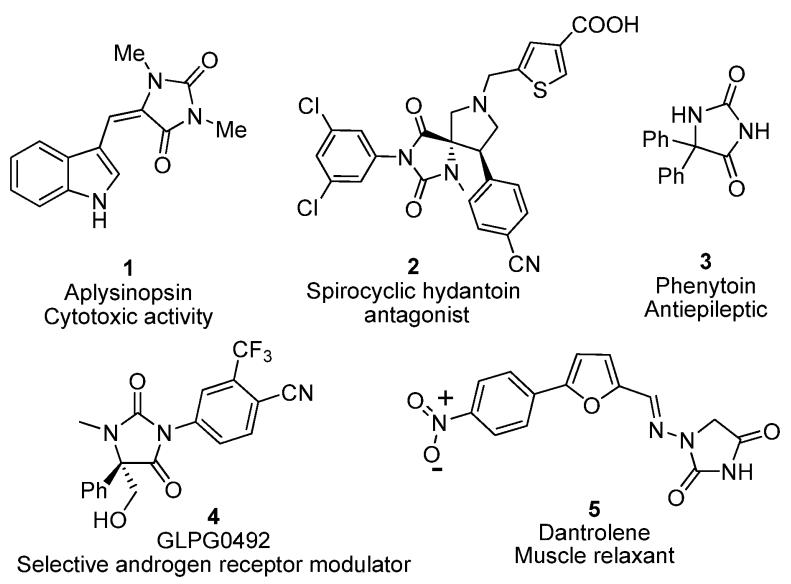

Fig. 1 Biologically active hydantoins.

\footnotetext{
${ }^{a}$ Department of Chemistry, Indian Institute of Technology Madras, Chennai 600036, India. E-mail: sbhaskar@iitm.ac.in; Fax: +91-44-2257-0545; Tel: +91-44-2257-4218

${ }^{b}$ Institut für Organische Chemie, Universität Regensburg, D-93040, Regensburg, Germany. E-mail: burkhard.koenig@chemi.uniregensburg.de; Fax: +49-941-9431717; Tel: +49-941-9434576

$\dagger$ Electronic supplementary information (ESI) available: Synthesis procedures and product characterization data. CCDC 907117 and 907118. For ESI and crystallographic data in CIF or other electronic format see DOI: 10.1039/c3cc41254g
}

Aplysinopsis reticulata (Dictyoceartida), exhibits cytotoxicity against cancer cells and shows ability to affect neurotransmitters (Fig. 1). ${ }^{7}$ The spirocyclic hydantoin 2 is a small molecule antagonist of LFA-1 (lymphocyte function-associated antigen-1). ${ }^{8}$ Phenytoin (3) is used in the treatment of epilepsy, whereas nitrofurantoin is an antimicrobial agent. ${ }^{9 a}$ Very recently, GLPG0492 4 has been found to be a potent partial agonist of the human androgen receptor. ${ }^{9 b}$ In addition, hydantoin dantrolene $\mathbf{5}$ is a skeletal muscle relaxant. ${ }^{9 c, d}$ Herbicides, such as (+)-hydantocidin, also contain the hydantoin moiety as an integral part of their structure. ${ }^{10}$ Moreover, substituted hydantoins are valuable intermediates for the synthesis of enantiomerically pure aminoacids through dynamic kinetic resolution. ${ }^{11}$

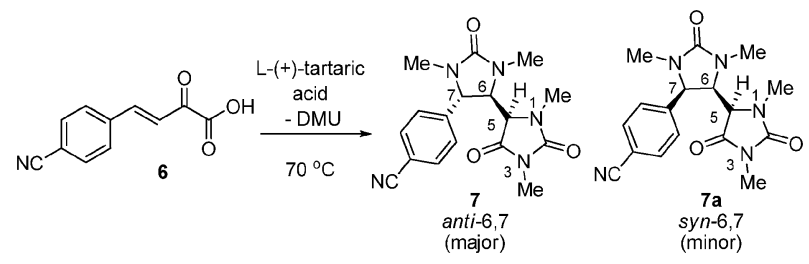

Scheme 1 Synthesis of a 1,3,5-trisubstituted hydantoin derivative.

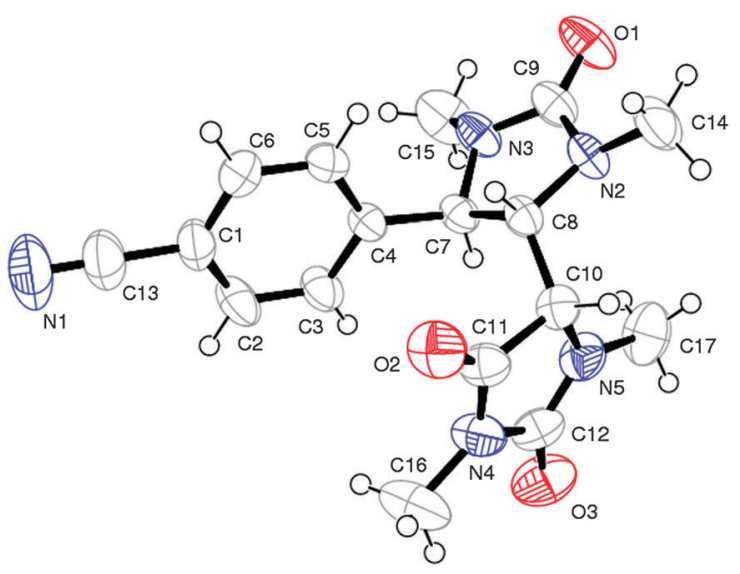

Fig. 2 ORTEP diagrams of hydantoin derivative 7 (anti-6,7); ellipsoids shown at $30 \%$ probability. 
A variety of synthetic methods exist in the literature for the preparation of hydantoins from diverse starting materials. ${ }^{1}$ The classic methods for the synthesis of hydantoin include the Bucherer-Bergs synthesis and the reaction of urea with carbonyl compounds. ${ }^{12}$ In particular, the synthesis of highly substituted hydantoins is accomplished by reacting $N$-substituted $\alpha$-amino acids or their esters with isocyanates. ${ }^{13}$ Alternative strategies for the synthesis of substituted hydantoins

Table 1 Synthesis of 1,3,5-trisubstituted hydantoins in melt ${ }^{a}$<smiles>[3H]/C=C/C(=O)C(=O)O</smiles><smiles>CN1C(=O)[C@H]([C@@H]2[C@H]([18OH])N(C)C(=O)N2C)N(C)C1=O</smiles>

Entry Substrate

Time

Yield $^{b} \mathrm{dr}$ antil

(h) Major anti-isomer (\%) syn

1<smiles>N#Cc1ccc(/C=C/C(=O)C(=O)O)cc1</smiles><smiles>Cc1ccc(C=CC(=O)O)cc1</smiles><smiles>O=C(O)/C=C/c1ccc2c(c1)OCO2</smiles>

4<smiles>O=C(O)/C=C/c1ccc(Br)cc1</smiles>

6<smiles>CN(C)C(=O)[C@H]1[C@@H](c2ccc(C#N)cc2)N(C)C(=O)N1C</smiles>
9<smiles>Cc1ccc([C@H]2C([C@H]3C(=O)N(C)C(=O)N3C)N(C)C(=O)N2C)cc1</smiles>
$2.8: 1$

$2.8: 1$<smiles>CC(C)[C@H]1C(=O)N(C)C(=O)N1C</smiles><smiles>CNC(=O)NN</smiles><smiles>CC(C)[C@H](c1ccc(Br)cc1)C1C(=O)N(C)C(=O)N1C</smiles>
$2: 1$

5<smiles>O=C(O)C(=O)C=Cc1cccc(Cl)c1</smiles>
5<smiles>CN1C(=O)C([C@H]2[C@@H](c3cccc(Cl)c3)N(C)C(=O)N2C)N(C)C1=O</smiles>

$2.4: 1$

6<smiles>O=C(O)/C=C/c1ccc(Cl)cc1Cl</smiles><smiles>CN1C(=O)[C@@H]([C@H]2[C@@H](c3ccc(Cl)cc3Cl)N(C)C(=O)N2C)N(C)C1=O</smiles>

$17^{\mathrm{Me}}$
${ }^{a}$ Reaction conditions: $\beta, \gamma$-unsaturated ketoacid $(1 \mathrm{mmol})$ in $\mathrm{L}$-tartaric acid-DMU melt $(1.5 \mathrm{~g})$ at $70{ }^{\circ} \mathrm{C} .{ }^{b}$ Isolated yield. use transition metal catalyzed reactions, ${ }^{14}$ Ugi condensation, ${ }^{15 a}$ reaction of $\alpha, \beta$-unsaturated carboxylic acids with carbodiimide, ${ }^{15 b}$ as well as the reaction of $\alpha$-amino amides with phosgene. $^{15 c}$

We have established low melting mixtures ${ }^{16 a, b}$ based on renewable resources as alternative reaction media for carrying out organic transformations. ${ }^{16 c-f}$ Recently, we reported the synthesis of dihydropyrimidinones (DHPM), pyrimidopyrimidinediones and indoles in $\mathrm{L}-(+)$-tartaric acid-urea melts. ${ }^{17}$

Herein, we report the first domino synthesis of 1,3,5-trisubstituted hydantoin from a $\beta, \gamma$-unsaturated ketoacid in low melting mixtures. Thus, $\beta, \gamma$-unsaturated ketoacid 6 reacts in a surprising transformation, upon exposure to $\mathrm{L}-(+)$-tartaric aciddimethylurea (DMU) melt conditions, to 1,3,5-trisubstituited hydantoin derivative 7 in excellent yield with good diastereoselectivity (Scheme 1).

The hydantoin derivative was obtained as a mixture of syn- and anti-diastereomers and the relative stereochemistry of the aryl and the hydantoin group was found to be anti to each other (major distereomer). The relative stereochemistry of the major anti-hydantoin derivative $\mathbf{1 3}$ was established using NOE experiments. ${ }^{18}$ Structure and relative stereochemistry of the major anti-6,7 isomer were confirmed using single crystal X-ray analysis (Fig. 2). ${ }^{19}$

Various $\beta, \gamma$-unsaturated ketoacids derived from electron rich as well as electron deficient aldehydes were found to react readily under the melt conditions to furnish the corresponding substituted hydantoin derivatives in good to excellent yields. ${ }^{19}$ The $\beta, \gamma$-unsaturated ketoacid $\mathbf{1 0}$ derived from piperonal furnished the corresponding hydantoin derivative $\mathbf{1 1}$ in very good yield. Similarly, the $\beta, \gamma$-unsaturated ketoacid 16 derived from sterically demanding aldehydes, such as 2,4-dichloro benzaldehyde, smoothly gave the corresponding hydantoin derivative 17 in excellent yield (Table 1). ${ }^{20}$ A plausible mechanism for the formation of trisubstituted hydantoin derivatives is depicted in Scheme 2.

Surprisingly, exposure of $\beta, \gamma$-unsaturated ketoacid 18, derived from furfural, to $\mathrm{L}-(+)$-tartaric acid-DMU melt resulted in the formation of a novel bicyclic alkylidine hydantoin derivative,
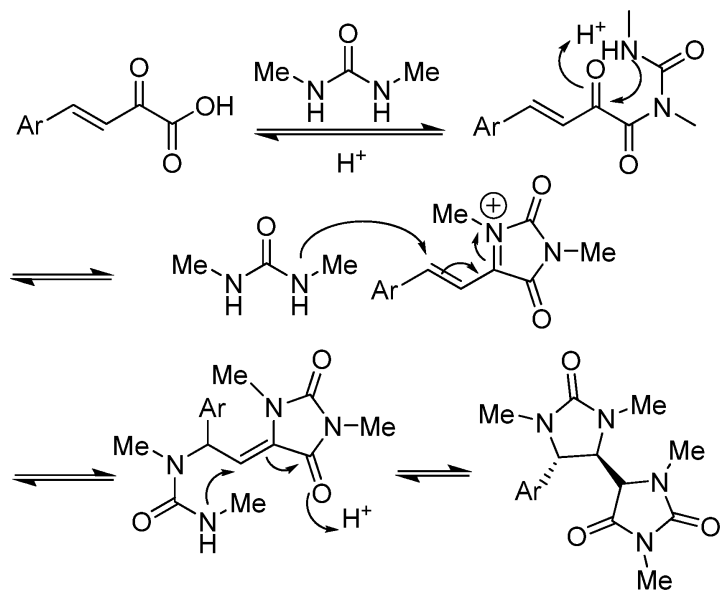

Scheme 2 Plausible mechanism for the domino synthesis of a novel 1,3,5trisubstituted hydantoin derivative. 


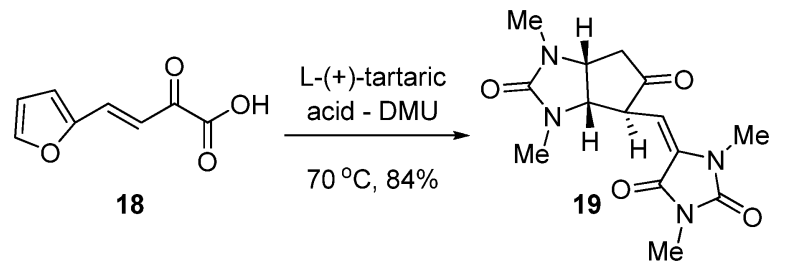

Scheme 3 Unusual formation of a bicyclic alkylidine hydantoin derivative.

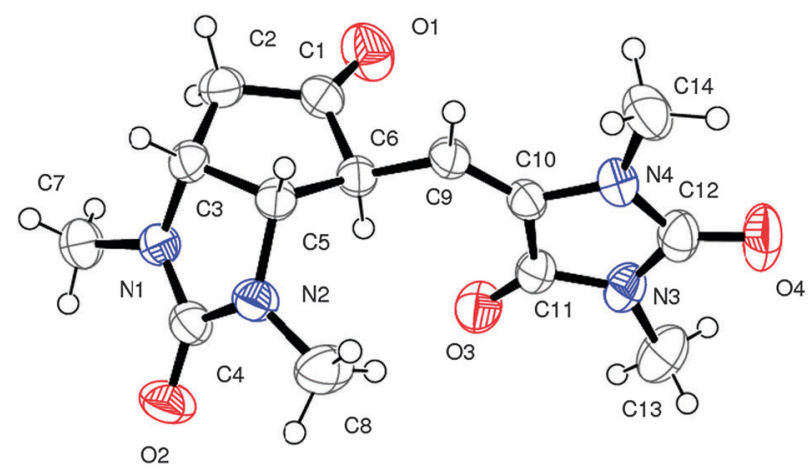

Fig. 3 Structure of compound 19 in the solid state; ellipsoids shown at $30 \%$ probability level.

19 (Scheme 3). The structure and relative stereochemistry of the bicyclic alkylidine hydantoin derivative 19 were confirmed using single crystal X-ray analysis (Fig. 3). ${ }^{18}$ This example is of particular interest, since a similar alkylidine hydantoin derivative has been used in the synthesis of the spirocyclic hydantoin antagonist 2 (Fig. 1). ${ }^{8}$

In conclusion, we have developed an efficient domino synthesis of 1,3,5-trisubstituted hydantoins in low melting mixtures. The substituted hydantoins were obtained in good yields under mild and environmentally benign reaction conditions. The melt medium serves simultaneously as a solvent, a catalyst and a reactant. The facile construction of functionalized hydantoins makes it a suitable protocol for the synthesis of potentially bioactive compounds.

We thank CSIR and DST (New Delhi) for financial support and DST-FIST (New Delhi) for infrastructure facility. S.G. (SRF) thanks IIT Madras, INDIGO (Indian-German exchange programme of the German Academic Exchange Service, DAAD) and BASF for the research fellowships. The authors thank Mr V. Ramkumar for providing the single crystal X-ray analyses.

\section{Notes and references}

1 For a review of hydantoin chemistry, see: $(a)$ M. Meusel and M. Gütschow, Org. Prep. Proced. Int., 2004, 36, 391-443; (b) E. Ware, Chem. Rev., 1950, 46, 403-470.

2 (a) J. C. Thenmozhiyal, P. T. H. Wong and W. K. Chui, J. Med. Chem., 2004, 47, 1527-1535; (b) P. Dang and A. K. Madan, J. Chem. Inf. Comput. Sci., 1994, 34, 1162-1166.

3 C. W. Brazil and T. A. Pedley, Annu. Rev. Med., 1998, 49, 135-162.

4 (a) J. Knabe, J. Baldauf and A. Ahlhelm, Pharmazie, 1997, 52, 912-919; (b) X.-Q. Qi, D. Newman and P. Dorian, J. Cardiovasc. Pharmacol., 1999, 34, 898-903.

5 (a) R. L. Hudkins, D. L. D. Hudkins and P. Doukas, Bioorg. Med. Chem. Lett., 1997, 7, 979-984; (b) A. A. Barbary, A. I. Khodair, E. B. Pedersen and C. Nielsen, J. Med. Chem., 1994, 37, 73-77.
6 (a) F. L. Wessels, T. J. Schawn and S. F. Pong, J. Pharm. Sci., 1980, 69, 1102; $(b)$ A. G. Caldwell, C. J. Harris, R. Stepney and N. Whittaker, J. Chem. Soc., Perkin Trans. 1, 1980, 495-505.

7 J. M. Chezal, G. Delmas, S. Mavel, H. Elakmaoui, J. Métin, A. Diez, Y. Blache, A. Gueiffier, M. Rubiralta, J. C. Teulade and O. Chavignon, J. Org. Chem., 1997, 62, 4085-4087.

8 D. Potin, M. Launay, F. Monatlik, P. Malabre, A. Fouquet, M. Maillet, E. Nicolai, L. Dorgeret, F. Chevallier, D. Besse, M. Dufort, F. Caussade, S. Z. Ahmad, D. K. Stetsko, S. Skala, P. M. Davis, P. Balimane, K. Patel, Z. Yang, P. Marathe, J. Postelneck, R. M. Townsend, V. Goldfarb, S. Sheriff, H. Einspahr, K. Kish, M. F. Malley, J. D. DiMarco, J. Z. Gougoutas, P. Kadiyala, D. L. Cheney, R. W. Tejwani, D. K. Murphy, K. W. Mcintyre, X. Yang, S. Chao, L. Leith, Z. Xiao, A. Mathur, B.-C. Chen, D.-R. Wu, S. C. Traeger, M. McKinnon, J. C. Barrish, J. A. Robl, E. J. Iwanowicz, S. J. Suchard and T. G. M. Dhar, J. Med. Chem., 2006, 49, 6946-6949.

9 (a) U. Domańska, A. Pobudkowska and P. Bocheńska, J. Chem. Eng. Data, 2012, 57, 1894-1898; (b) F. Nique, S. Hebbe, N. Triballeau, C. Peixoto, J.-M. Lefrançois, H. Jary, L. Alvey, M. Manioc, C. Housseman, H. Klaassen, K. V. Beeck, D. Guédin, F. Namour, D. Minet, E. V. Aar, J. Feyen, S. Fletcher, R. Blanqué, C. R. Jagerschmidt and P. Deprez, J. Med. Chem., 2012, 55, 8236-8247; (c) J. O. McNamara, in Goodman \& Gilman's The Pharmacological Basis of Therapeutics, ed. J. G. Hardman and L. E. Limbird, McGraw-Hill, New York, 10 edn, 2001, ch. 21, pp. 528-531; (d) T. Krause, M. U. Gerbershagen, M. Fiege, R. Weißhorn and F. Wappler, Anaesthesia, 2004, 59, 364-373.

10 M. Shiozaki, Carbohydr. Res., 2002, 337, 2077-2088.

11 S. G. Burton and R. A. Dorrington, Tetrahedron: Asymmetry, 2004, 15, 2737-2741.

12 M. Beller, M. Eckert, W. A. Moradi and H. Neumann, Angew. Chem., Int. Ed., 1999, 38, 1454-1457.

13 (a) I. B. Blogoeva, M. M. Toteva, N. Ouarti and M.-F. Ruasse, J. Org. Chem., 2001, 66, 2123-2130; (b) J. Matthews and R. A. Rivero, J. Org. Chem., 1997, 62, 6090-6092; (c) A. Boeijen, J. A. W. Kruijtzer and R. M. Liskamp, Bioorg. Med. Chem. Lett., 1995, 5, 47-50.

14 (a) T. Miura, Y. Mikano and M. Murakami, Org. Lett., 2011, 13, 3560-3563; (b) Y. Kuninobu, K. Kikuchi and K. Takai, Chem. Lett., 2008, 740-741; (c) M. Beller, M. Eckert, W. A. Moradi and H. Neumann, Angew. Chem., Int. Ed., 1999, 38, 1454-1457.

15 (a) J. M. Ignacio, S. Macho, S. Marcaccini, R. Pepino and T. Torroba, Synlett, 2005, 3051-3054; (b) A. Volonterio, C. R. Arellano and M. Zanda, J. Org. Chem., 2005, 70, 2161-2170; (c) D. Zhang, X. C. Xing and G. D. Cuny, J. Org. Chem., 2006, 71, 1750-1753.

16 (a) G. Imperato, E. Eibler, J. Niedermeier and B. König, Chem. Commun., 2005, 1170-1172; (b) C. Ruß and B. König, Green Chem., 2012, 14, 2969-2982; (c) G. Imperato, S. Höger, D. Lenoir and B. König, Green Chem., 2006, 8, 1051-1055; (d) F. Ilgen and B. König, Green Chem., 2009, 11, 848-854; (e) G. Imperato, R. Vasold and B. König, Adv. Synth. Catal., 2006, 348, 2243-2247; $(f)$ C. Ruß, F. Ilgen, C. Reil, C. Luff, A. H. Begli and B. König, Green Chem., 2011, 13, 156-161.

17 (a) S. Gore, S. Baskaran and B. König, Green Chem., 2011, 13, 1009-1013; (b) S. Gore, S. Baskaran and B. König, Adv. Synth. Catal., 2012, 254, 2368-2372; (c) S. Gore, S. Baskaran and B. König, Org. Lett., 2012, 14, 4568-4571.

18 The irradiation of $\mathrm{H}_{c}$ proton resulted in the enhancement of signal intensities of $\mathrm{H}_{\mathrm{a}}$ and $\mathrm{H}_{\mathrm{b}}$ protons by 1.4 and $2.2 \%$, respectively, indicating that these protons are in close proximity to $\mathrm{H}_{\mathrm{c}}$. See ESI $\dagger$ for details. A mechanistic proposal for the formation of compound 19 is given in the ESI. $†$ All obtained compounds were racemic.

19 CCDC 907117 (7) and 907118 (19). $\uparrow$ Compound 7: $\mathrm{C}_{17} \mathrm{H}_{19} \mathrm{~N}_{5} \mathrm{O}_{3}$, $M=341.37$, crystal system, space group monoclinic, $P 2(1) / c$; unit cell dimensions $a=10.2755(5) \AA \alpha=90^{\circ}, b=18.0150(9) \AA, \beta=$ 116.623(2) $, c=10.8800(6) \AA, \gamma=90^{\circ}$, volume 1800.49(16) $\AA^{3}, Z=4$; reflections collected/unique $11735 / 4167[R(\mathrm{int})=0.0217]$; final $R$ indices $[I>2 \sigma(I)], R_{1}=0.0501, \mathrm{w} R_{2}=0.1265 ; R$ indices (all data), $R_{1}=$ $0.0818, \mathrm{w} R_{2}=0.1459$. Compound 19: $\mathrm{C}_{14} \mathrm{H}_{18} \mathrm{~N}_{4} \mathrm{O}_{4} ; M=306.32$, crystal system, space group monoclinic, $P 2(1) / n$; unit cell dimensions $a=$ 6.6929(3) $\AA \alpha=90 \mathrm{deg}, b=9.8842(6) \AA, \beta=97.236(3)^{\circ}, c=22.5275(14) \AA$, $\gamma=90^{\circ}$; volume 1478.41(14) $\AA^{3} ; Z=4$; final $R$ indices $[I>2 \sigma(I)], R_{1}=$ $0.0442, \mathrm{w} R_{2}=0.1058 ; R$ indices (all data) $R_{1}=0.0773, \mathrm{w} R_{2}=0.1204$.

20 The melt medium is readily recovered and recycled up to three cycles without any significant loss of activity or yield. 